\title{
Participation and the Quality of Democracy in Portugal
}

A participação e a qualidade da Democracia em Portugal

La participation et la qualité de la Démocratie au Portugal

\section{Camila Rodrigues}

\section{OpenEdition}

\section{Journals}

Electronic version

URL: http://journals.openedition.org/rccs/6111

DOI: $10.4000 /$ rccs.6111

ISSN: 2182-7435

Publisher

Centro de Estudos Sociais da Universidade de Coimbra

Printed version

Date of publication: 1 December 2015

Number of pages: 75-94

ISSN: 0254-1106

\section{Electronic reference}

Camila Rodrigues, " Participation and the Quality of Democracy in Portugal », Revista Crítica de Ciências Sociais [Online], 108 | 2015, Online since 16 December 2015, connection on 20 April 2019.

URL : http://journals.openedition.org/rccs/6111; DOI : 10.4000/rccs.611 


\section{CAMILA RODRIGUES}

\section{Participation and the Quality of Democracy in Portugal}

Taking as its starting point the debate on the contribution made by participation to the quality of democracy, this article seeks to situate the issue within the context of Portugal. In the last 40 years, Portugal has experienced three critical junctures: the April revolution, EU membership and the economic crisis. Revolutionary ideals were consigned to the background as new ideals emerged, associated with a focus on economic competitiveness. Inequality, indebtedness and insecurity have since increased, leading to responses that seek to reverse this trend. Increasing participation may be considered one interesting response: in addition to new social movements, the old movements that have remained dormant, embodied in initiatives such as the SAAL (Local Ambulatory Support Service), may revive to express support for a more inclusive society.

Keywords: inclusive society; democratic participation; SAAL; urban movements.

\section{Introduction}

The idea of democracy as the "good" form of government is rather complex and, unsurprisingly, debatable. It is a complex concept that has come a long way since it was initially coined in the 5 th century BC, in the context of the Greek city states. Generally speaking, it can be regarded as morally desirable if it promotes socially valued outcomes, such as equality, justice and legitimacy, and functionally advantageous if it allows for effective and smooth governance that produces the expected results within a reasonable period of time. However, interesting as the subject may be, the purpose of this article is not to discuss the multiple definitions and dimensions of democracy or to analyse its desirability, but to question its quality, understood in terms of the achievement of the above mentioned outcomes.

Taking equality as a starting point, democracy may be considered solely as equality in terms of access to the electoral system - one citizen, one vote or from a broader perspective that adds several factors to the equation which may affect each citizen's capacity to actually influence the political processes 
that concern them. These include factors such as economic inequality, which may place certain individuals in a privileged position compared to others in terms of distribution of resources and opportunities, and factors such as the establishment of patronage networks that affect the way services and goods are distributed among citizens, favouring those who are involved in asymmetric, politically advantageous relations. Given these factors, it can be argued that electoral equality, per se, is not enough, and that it is necessary to implement compensation mechanisms to correct any tendency towards political inequality.

This raises the matter of the role played by citizens in a democracy. If additional mechanisms are to be implemented in addition to elections in order to make the system of political representation more equal, they will certainly demand something from citizens in the form of a deeper involvement in politics. The extent of this involvement, the ways in which it may be achieved and its possible consequences then become a matter of debate, meaning that we are faced with two opposite perspectives on the issue of participation: on the one hand, democratic governance may involve the direct participation of members of a society in decision-making processes; on the other hand, their participation may only imply selecting representatives to make decisions for them.

Pateman (1970) identified these two opposite poles through the distinction between contemporary and participatory theories of democracy. The contemporary theory of democracy establishes the heart of the democratic system in the electoral competition between political elites. Political equality represents equality of access to the electoral system and participation consists of exercising the right to vote. From this perspective, the level of participation should not exceed the minimum required to maintain the democratic method, since a more intense form of participation could put potentially unresolvable pressure on the political system.

The theory of participatory democracy, inspired by classical theorists such as Rousseau, Tocqueville and John Stuart Mill, considers that the existence of representative institutions on a national level does not constitute a sufficient guarantee of democratic quality. Socialization for democracy should exist in various social spheres, so that the desired psychological traits can be developed through the experience of participation which, in addition to promoting equality, also has educational and integrative functions.

The debate on the role of participation in contemporary democracy is not limited to the theoretical field, but extends to the operational level underlying both political discourse and practice. At this level, the object is not a scientific one, aimed at furthering knowledge in itself, but assumes a practical 
nature, since it intends to promote tangible and desirable outcomes, such as the prosperity and well-being of a given society. As Procacci (1991) argues, it is thus an object on which political agents will act, and therefore explicitly reflects the perspective of the dominant powers. In order to analyse the practical implications of participation, it is therefore necessary to situate it in a given time and place, since empirical confirmation is fundamental to assessing the extent to which it may promote democratic quality.

\section{Portugal between Critical Junctures - From Revolution to Bailout}

Portugal offers fertile ground for such research. In April 1974, the "Carnation Revolution" heralded the third wave of democratic transition, when a military coup determined the end of a fascist regime that had lasted for over 40 years. The revolutionary period was marked by intense political instability, with two presidents and six provisional governments in two years. This instability was determined by the heterogeneous emerging political forces, who had only their opposition to the former fascist regime in common. The moderates relied mainly on electoral legitimacy, while the most radical left wing forces, sidelined in the elections, appealed to a revolutionary legitimacy supported by popular mobilization, thus placing grassroots organizations rather than parties at the heart of the political system.

Popular movements, namely the urban movement, ${ }^{1}$ were intensely active during the revolutionary period, which made them a potential political weapon to be used by the contending forces. However, as noted by Ramos Pinto (2008), the urban movement focused mainly on the right to housing and, in general, refused to radicalise, opting instead for a moderate course of action. This option supported the outcome of the political struggle, with the victory of the moderates in November 1975. It was the beginning of the path towards a pluralist representative democracy, distanced from the popular direct democracy that had been proposed by the radicals.

The Portuguese path to democracy was heavily influenced by membership of the European Economic Community (EEC), which it joined in 1986. As observed by Royo and Manuel (2003), Portuguese policymakers in the 80s relied on EEC membership to help consolidate the recent democratic institutions, which implied the modernisation of economic structures and normalization of relations with other member states in a context marked by the

\footnotetext{
${ }^{1}$ At the time of the April 1974 Revolution, approximately $25 \%$ of the population in mainland Portugal were living in homes that had no privacy, safety or comfort. In about two and a half million households, $67 \%$ had no toilet facilities, $60 \%$ were not served by the sewage system, $53 \%$ had no electricity and $52 \%$ had no water supply. The housing shortage was estimated at about 600,000 households (Bandeirinha, 2007: 68).
} 
instability of the institutions that had been established during the transition. The integration process entailed the promotion of economic competition, privatization of public enterprises, restructuring of the industrial sector and a process of economic deregulation, all measures that drove Portugal further away from the socialist path.

The influence of the European Union (EU) on the political development of Portugal is therefore one explanatory factor that should be addressed and to some extent can be viewed as a turning point, a new critical juncture that somehow reversed the effects of the one that had preceded it, namely the revolutionary transition to democracy and its socialist inspiration. The EU neo-liberal orientation, enforced through the influence of the Thatcher governments, encouraged member states to privatise and deregulate with the aim of intensifying market competition, therefore reducing the state's role in the provision of resources whilst expanding the role of the markets. As Hall (2003) pointed out, the idea underlying this process, facilitated by the single market and economic and monetary union, was that more intense competition makes organizations perform more efficiently, an objective openly prioritized over the cooperation proposed by the socialist approach embedded in the first draft of the Portuguese Constitution.

This trend was accentuated with the revision of the Lisbon Strategy in 2005 which, following the Kok (2004) report, proposed to reinforce EU competitiveness through employment and economic growth. This preference for a neoliberal concept of the rights and responsibilities of citizenship instead of the equalitarian approach envisaged in the initial formulation of the Strategy reflected the growing influence of a majority of right-wing governments at EU level, as a result of the enlargement process. The design and implementation of the Europe 2020 Strategy in a context of economic crisis and strengthening of the inter-governmental rationale, with Germany and France becoming the main decision-making forces while the influence of the European Commission continued to decline, accentuated the neoliberal orientation conferred on European Community economic and social policies.

In the midst of this process, Portugal missed out on growth and in 2011, following the example of Greece and Ireland, had to seek and agree to a three-year 78-billion-euro bailout with the International Monetary Fund (IMF), the European Commission (EC) and the European Central Bank (ECB), after the opposition parties rejected Socrates's IV Stability and Growth Program (PEC IV). The demands of the financial assistance programme, which aimed for a cut of $5.9 \%$ of the gross domestic product in the budget deficit for that year, involved implementing a comprehensive 
economic programme that has been severely affecting the quality of life of many Portuguese citizens, with increases in taxes and user fees, and cuts in social and unemployment benefits.

Portugal was already one of the most economically unequal countries in the EU, after Lithuania, Latvia and Spain. In 2010, Lithuania recorded the most unequal distribution of income, with a Gini index of $37 \%$, followed by Latvia with $35.9 \%$. Spain came third with $34.4 \%$ and Portugal was close behind with $33.7 \%$, while the EU-28 average was 30.5\%. ${ }^{2}$ From 1985 to 2009 , the concentration of income in the most affluent groups had deepened in Portugal. Between 1976 and 1982, a socialist-inspired phase prior to the constitutional revision of 1989, the share of the total income controlled by the richest groups in Portugal had declined, but since the late 80s it began to increase and, according to tax statistics, $1 \%$ of the richest Portuguese citizens held $9.8 \%$ of the total income in $2005 .{ }^{3}$

In a study drawing on data produced up to 2009, Farinha Rodrigues (2012) detected a strong reinforcement of wage inequality, with the Gini index increasing from $28.4 \%$ to $34.4 \%$. After an initial period of accentuated inequality from 1985 to 1994, a period of attenuation of wage disparities followed in the second half of the 90s, although it was not sufficient to reverse the previous decline. The highest income decile saw its share increase from $24 \%$ to $29.8 \%$ of the total gain between 1985 and 2009 . This roughly coincides with Portugal joining the EU and the PSD Cavaco Silva governments ${ }^{4}$ which, as already noted, entailed profound structural reforms that broke with the revolution's socialist orientations. The main goal was to make the transition to a liberal and competitive economic system based on private ownership, which would enable Portugal to align itself with its European partners.

\section{From Proletariat to "Precariat"}

Considering the data, it may be concluded that the implementation of capitalism in Portugal, particularly in the periods of greatest liberalisation, has promoted economic inequalities to a degree that may seriously affect the quality of democracy. This debate leads to the unavoidable dilemma

\footnotetext{
2 Accessed on 28.01.2015 in Eurostat, at http://ec.europa.eu/eurostat/tgm/table.do?tab=table\& language $=$ en $\&$ pcode $=$ tessi190. .

3 Accessed on 28.01.2015 in Observatory of Inequalities, at http://observatorio-das-desigualdades. cies.iscte.pt/index.jsp? page $=$ indicators\&id $=229 \&$ lang $=$ pt.

4 Aníbal Cavaco Silva (Social Democratic Party - PSD) was elected Prime Minister for three consecutive terms: in a minority government from 1985 to 1987 and in two majority governments from 1897 to 1991 and from 1991 to 1995.
} 
of capitalism versus socialism, which becomes even more relevant in a context of austerity that reinforces the retraction of social rights, seriously compromising any alleviation of the inequalities produced by the capitalist system. In such a situation, capitalism does seem to contain the seeds of its own destruction, as suggested by Marx (1977), since the unrestrained concentration of economic power in the hands of a few leads to the impoverishment of many.

In Marx's perspective, the impoverished proletariat would take revolutionary action, but in modern capitalist societies workers are no longer traditional factory labourers and tend to be dispersed in a rather anonymous "precariat" which faces challenges in mobilising around a common goal, not to mention complete social transformation. As labour rights have shrunk, with the most radical challenge being the declaration by the Constitutional Court that proposals to facilitate the system for terminating employment contracts are unconstitutional, the unemployment rate has risen, totalling $6.2 \%$ in 2013.5

In this context, more aggressive and unequal forms of working relations and commercial activities ${ }^{6}$ disguised as work have been flourishing and absorbing many of those who lost their jobs during the crisis. This kind of work is a good example of the increasingly precarious nature of labour relations. More and more companies are adopting aggressive sales tactics in which the product does not matter and needs must be created by an army of heterogeneous labourers who often work without a contract or even without a salary and depend entirely on what they are able to sell, in a context of severe economic recession that necessarily affects the purchasing power of the target families.

For this to be sustainable it is fundamental to encourage workers to believe that their situation is a desirable one. This assumption is upheld by the most cherished liberal principles of meritocracy and equal opportunities. These ideals are necessarily illusory in this context, since senior sales staff who have experience, clients and contacts and receive business leads from the company are not in the same situation as newcomers. Despite this, the illusion is enforced through company workshops provided by personal motivators, usually supported by a dubious pseudo-scientific neuro-linguistic programming approach, and through fierce peer pressure, in which the success of a select few is constantly glorified.

\footnotetext{
${ }^{5}$ Accessed on 28.01.2015, in Data Base of Contemporary Portugal (PORDATA), at http://www. pordata.pt/Portugal/Taxa+de+desemprego+total+e+por+sexo+(percentagem)+(R)-550.

${ }_{6}$ The author carried out participant observation in several commercial activities (insurance, real estate, telecommunications and publishing) from 2008 to 2013.
} 
Paradoxically, it is in this contemporary "precariat" that the most radical liberal ideals of competition are more strongly enforced, or indoctrinated, and become a matter of survival for those who depend on sales commissions to make ends meet. It is therefore relevant to wonder whether they will conform, mobilize for their employment rights or take revolutionary action for broader social change.

In April 2014 call centre workers, who represent one of the most extreme forms of the modern "precariat", formed a union, "Are you connected?", to defend their rights, since they felt they were not being properly represented by the traditional unions who were not prepared to address the new forms of exploitation which this type of employment entailed. With a broader scope, the "Inflexible Precarious" association, which views austerity as the "end of the line for democracy", strives to eliminate all precarious employment and exploitation of the labour force. In their manifesto they argue that precarious employment and the new issues of the working world challenge unionism but do not oppose it, and call for joint action that covers both precarious workers and the unemployed.

These initiatives reveal that workers are mobilizing for their employment rights, although it is a restricted movement that does not suggest any broader transformation or significant challenge to the economic and political system that created the precarious working conditions in the first place. Despite the economic crisis, the austerity measures that have been implemented and the impoverishment that this has generated, nothing like the "Syriza" or the "Podemos" movements is emerging in the Portuguese political arena. A rather timid 3D Manifesto appeared but the left failed to combine forces and in the 2014 European elections the main political parties continued to dominate, as well as the usual power shifts between them, with the Socialist Party (PS) obtaining $31.46 \%$ of the vote $(26.58 \%$ in 2009) and the Socio-Democrat Party/Popular Party coalition (PPD/PSD. CDS-PP) $27.71 \%$ (31.71\% in 2009). The left wing coalition between the Communist Party and the "Green" Ecological Party (PCP-PEV) came third with $12.68 \%$ of the votes $(10.66 \%$ in 2009$) .{ }^{7}$ The results of the 2013 local elections also favoured the PS, which obtained $36.29 \%$ of the votes (37.67\% in 2009), followed by the PPD/PSD with $16.70 \%$ $(22.95 \%$ in 2009$)$. As in 2009, the PCP-PEV was the third political force with $11.06 \%$ of the votes $(9.73 \%$ in 2009$) .{ }^{8}$ In the 2015 legislative

\footnotetext{
${ }^{7}$ Accessed on 28.01.2015, in Ministry for Internal Affairs (MAI), at http://www.eleicoes.mai. gov.pt/europeias2014/\#none.

${ }_{8}$ Accessed on 28.01.2015, in Ministry for Internal Affairs (MAI), at http://www.eleicoes.mai. gov.pt/autarquicas2013/\#none.
} 
elections the ruling right wing coalition lost its majority but still won with $36.86 \%$ of the votes (as opposed to $32.31 \%$ for the PS), while Cavaco Silva explicitly banned the PS and its left wing Eurosceptic supporting parties from forming a government, based on the argument of national interest. Creditors take precedence over voters and austerity measures cannot be challenged.

\section{The Urban Revolution}

If the seeds of change do not lie in the "precariat", where can they be? Harvey (2012: 130) suggests altering the concept of proletariat to include the "hordes of unorganized urbanization producers" in order to "explore their distinctive revolutionary capacities and powers". From this perspective, neighbourhood organisation is fundamental in a context of advanced capitalism that erodes conventional workplaces and makes it necessary to combine organization based on the workplace with organization based on living conditions.

In Portugal, despite opting for capitalism, the end of the revolutionary period did not imply the demobilization of the urban movement. Instead, it encouraged it to reconfigure and adapt to a new context that demanded political stability in democratic governance. During the revolutionary period many neighbourhood commissions emerged spontaneously and some evolved into more formal organizations, such as neighbourhood associations and housing cooperatives. These organizations are a part of present-day Portuguese democracy. They allow citizens to aggregate their interests and defend their goals in a context in which growing dissatisfaction with a representative democracy frequently associated with technocratic governance mechanisms, social individualization and the globalization not only of the markets but also of decision-making processes, has highlighted participation as a factor that may contribute to the quality of democratic governance (Smismans, 2006). From this perspective, participation becomes more than a vehicle for equality, but also promotes political legitimacy in complex contemporary democracies.

Having considered two of the fundamental qualities of democratic governance - equality and legitimacy - it is now necessary to consider justice. Given the territorial dimension of urban movements, the most appropriate concept of justice is a concept of spatial justice that addresses the spatially balanced distribution of resources and opportunities to use them (Soja, 2009). From this perspective, the political organization of space emerges as a tool for the production and reproduction of social justice or injustice. As Soja points out, the way in which the urban system functions may constitute a source of inequality and injustice if the decision-making processes 
are controlled by those who have more resources, which tends to happen in a capitalist society that places the decision-making processes largely in the hands of a market that favours economic growth over democratic quality.

As argued by Fainstein (2009), the just city demands a more balanced distribution of political power in a context in which investment resources tend to be controlled by small groups that create and reinforce subordination. In this context, neighbourhood organizations constitute vehicles for civic involvement and mobilization that may contribute to a more balanced distribution of decision-making political power on a territorial level, by involving citizens.

Data from the Registo Nacional de Pessoas Colectivas (RNPC - national registry of organizations), ${ }^{9}$ which records all the organizations that have been founded in Portugal since 1978 or still existed in that year, reveals that while the number of neighbourhood associations founded each year has been stable, the number of housing cooperatives has been decreasing. This trend is also common to the associational and cooperative universes beyond housing: data from the Instituto Nacional de Estatística (INE-National Statistical Institute, 2013a: 5-6) shows that in 2010 associations and other similar organizations were virtually hegemonic in the Portuguese third sector and accounted for $94 \%$ of all units. Cooperatives were the second largest organizational group, but by a very wide margin, constituting $4 \%$ of all organizations.

The decline of the cooperative movement suggests that the factor which differentiates cooperatives from associations - their economic nature has been hindering their development. The sector policy was often ambiguous and contradictory: although institutional bodies and constitutional measures were created and defined to protect the cooperative sector, legislation did not always follow this tendency. For instance, in the mid-80s the cooperative sector was denied access to certain economic resources, such as life insurance policies, transport of merchandise and vehicle rental (Namorado, 1999).

As for housing cooperatives, it can be seen that cooperative projects reached a peak in 1989 with 4,582 houses contracted, but then decreased dramatically (IHRU, 2007: 25-26). During and immediately after the revolution, cooperatives were seen as a valuable instrument for resolving the severe housing needs that affected the country. According to the IHRU,

9 This data was made available by the project "Civil Society and Democracy - Portugal in a comparative perspective", implemented by the Center for Sociological Studies of the Universidade Nova de Lisboa (CESNOVA) and financed by the Portuguese Foundation for Science and Technology (FCT). 
in the late 70s the cooperative movement was responsible for the development of residential complexes, with the support of the local authorities, which were innovative in their approach to user involvement. These projects presented high quality standards for housing, outdoor spaces and social facilities, which were unprecedented for housing built at controlled costs.

The end of the Housing Promotion Fund (FFH) in the early 80s temporarily disturbed the ongoing cooperative processes, but the creation of the National Housing Institute (INH) favoured a new phase of development that hinted at a clear political option to support the sector. At the end of the $80 \mathrm{~s}$, a government plan to promote controlled cost housing raised expectations that were frustrated by unfavourable policy measures and the absence of any effective dialogue between the government and the social partners in the construction sector. As a consequence, housing cooperatives began to experience difficulties in developing their projects, particularly those directed towards the most disadvantaged social groups. The 90s therefore represented a period in which the previous expectations for consolidation and growth in the cooperative housing sector shrank.

With the growing imposition of the market economy, the state itself has been withdrawing from housing construction, understood as an unwelcome expense that generates unresolvable social problems which should be left in the hands of the market (Carreiras et al., 2011). Consequently, the market did take over. The number of houses built between 1997 and 2012 is due almost entirely to private initiative, since the cooperative and public sectors only played a minor role in these developments. House building reached a peak in 2002 with the completion of 129,278 houses, $124,864(96.5 \%)$ of which were private initiatives, $2,555(2 \%)$ public initiatives and 1,859 (1.5\%) built by cooperatives. From then on the crisis in the building sector led to a constant decrease in the number of houses built each year, reaching its lowest point in 2012 with a total of just 34,294 . The crisis affected all sectors - private, public and cooperative - transversely, with only 33,703 (98.3\%), 507 (1.5\%) and $84(0.2 \%)$ houses built respectively in that year, but the relative weight of both the public and the cooperative sectors decreased even more in comparison with 2002 (INE, 2013b: 31).

Bingre do Amaral (2011) notes the gradual transformation of housing into a financial asset detached from its real purpose, a phenomenon that has been supported by urban planning legislation that favours private ownership of land as an economic factor, thus undermining its social function. As such, the system of spatial planning determines which land will absorb, through its price, the available credit for mortgages and, consequently, which entities 
will benefit from the future revenue generated by these mortgages - the construction companies and the banks.

Despite some attempts to liberalize and modernize the rental market, the incentives have been very tenuous and ownership has remained the favoured means of access to housing (Figueiredo, 2004:311-312). This has been facilitated by low tax rates, subsidized credit schemes and favourable legislation on loans ${ }^{10}$ which artificially increased the purchasing power of the Portuguese population and encouraged home ownership transacted by construction companies since, for the reasons listed above, the final cost proposed by housing cooperatives was not significantly more competitive - housing cooperatives, working in a capitalist system, organized their activities around private instead of collective property (selling instead of renting).

Easy access to credit made the housing market more dependent on interest rates than on demographic pressure or the real income of the Portuguese population. Moreover, a favourable fiscal policy encouraged the retention of houses, including vacant ones, for speculation, thus artificially lowering the supply and turning it into a "good, safe investment" for everyone. This led to another problem: an excess of houses on the market. Portugal has moved from a situation in which there was an acute shortage of adequate households to one in which there is a surplus of available houses and today has the second highest ratio of houses per family (1.5) in the EU, after Spain (Bingre do Amaral, 2011: 34).

In the last three decades housing provision has grown considerably, together with the average comfort levels of the dwellings. Approximately $18 \%$ of homes were built after 1960 and $30 \%$ were built during the last two decades (Marques et al., 2014:2). However, this growth in numbers did not mean the end of some persistent problems, nor did it prevent new ones from emerging, such as overcrowding, household insolvency and indebtedness, a lack of adequate bathroom facilities and housing amenities (such as thermal comfort), and an increase in the number of senior citizens living alone. The deterioration of older buildings is also a persistent problem, namely in the historic centres of major cities and, given the poor quality of recent construction projects, is expected to intensify in the future, exacerbated by the economic crisis which will make it difficult for owners to carry out maintenance work on their houses.

\footnotetext{
${ }_{10}$ The results were notorious: in 1985, 27,700 mortgage contracts were signed, but by 1994 the number had increased to over 83,000. Between 1991 and 1994 the number of contracts increased at an annual average rate of $25 \%$ and the overall contract value grew at an annual average rate of $45 \%$. Within this time period subsidized loans represented approximately half of the total loans for house purchases.
} 
A significant increase in the number of houses repossessed by banks can also be observed, as people fail to meet their housing loan commitments. In the early days of the crisis, 127,377 people were in a situation of mortgage default in 2009, but by 2013 this had risen to 145,766 (ibidem: 12). The economic crisis led to a decrease in purchasing power that affected most of the population, including the middle class, a situation made worse by the reversal of credit policies by the banks, which began to adopt much more restrictive measures. This was due firstly to an increase in the cost of capital, which made it difficult for the banks to finance themselves and, secondly, to a sharp deterioration in expectations for economic activity in general and the housing market in particular, which included lower expectations on the part of the banks regarding the ability of consumers to meet mortgage commitments.

Portugal is therefore facing a crisis in its housing sector that affects many citizens, in particular those with fewer economic resources. The economic crisis has seriously hindered the capacity of local authorities to invest in social housing which, coupled with the rather uncompromising stance of the political agents in question, has had severe consequences for many families. The main social housing program in the Portuguese democratic period, the Special Rehousing Program (PER), is based on mass construction projects and the concentration of multi-problem populations in a precarious economic situation (Fonseca Ferreira, 1994). Moreover, it takes a markedly static approach to the problem: only people living in sub-standard housing registered by the local authorities in 1993 have the right to a house. This approach is inadequate since the programme took a long time to implement; in the municipality of Amadora, for example, it is still ongoing.

The PER had built over 31,000 households by 2005 , out of a total of 35,000 contracted overall. Although construction work initially progressed at an average of 4,000 houses per year, after 2002, following the crisis in the public construction sector, the number fell considerably to less than 300 houses per year, reaching a low of 271 in 2004 (IHRU, 2007: 30). The initial rigid approach and the delay in implementing the programme have created serious difficulties and, in the most extreme cases, led to the forced eviction of those who applied after registration.

These housing problems led to the formation of the "Habita - Collective for the Right to Housing and the City" association, ${ }^{11}$ a group initially organized informally by citizens concerned with these matters who felt the

${ }^{11}$ Its founding assembly took place in September 2014. 
need to strengthen its organizational capacity and resources and involve new members. The group had been active since 2005 in supporting the self-organization of residents affected by demolitions in self-built shanty neighbourhoods, particularly in the "Bairro de Santa Filomena" in Amadora and the "Bairro da Torre" in Loures. More recently, the group has been dealing with the amendment of the leasing law, problems with mortgage loans and gentrification in urban centres. As a grass-roots organization involved in the fight for better working conditions, its action is restricted to one specific area, in this case the right to housing.

\section{The Analytical Relevance of the SAAL in the Present Context}

As other countries faced with severe austerity measures develop broad left wing alternatives to the capitalist system, in Portugal restricted grass-roots movements have emerged to deal with specific issues, since the left wing parties and initiatives remain unable to present a feasible alternative. It is therefore relevant to ask why this is the case, given Portugal's recent revolutionary past which could have provided citizens with some incentive to take action - whether revolutionary or not - in the face of harsh times.

The revolution presented a valuable opportunity to affirm neighbourhood movements, which found themselves empowered in a context in which the state was fragile due to the transition process and social hierarchies were being redefined. Moreover, they were confronted with receptive policy-makers who regarded their claims in a favourable light. One policy-maker in particular played a vital role in this process, namely Nuno Portas, an architect who was Secretary of State for housing and urbanism during the first three provisional governments, in 1974 and 1975. As noted by Bandeirinha (2007), he and other co-workers represented a new progressive understanding of urban planning within an increasingly obsolete and rigid political structure that resisted any possibility of change. Despite the obvious housing problems it faced, the political system resisted the alternative approaches discussed by a group of young, scientifically aware architects and their influence remained confined to a small circle of specialists.

It was the revolution that finally provided the opportunity to implement the experimental participatory ideas that had previously been sidelined, and one experience in particular cannot be overlooked in any analysis of participation. The SAAL (Serviço de Apoio Ambulatório Local - Local Ambulatory Support Service) was published in the Official Gazette of August $6^{\text {th }} 1974$, presented as a housing programme: 
... Aimed at deprived social groups with an internal organization that allows for their immediate involvement in self-managed solutions, with the support of the state with regard to land, infrastructures, technical assistance and financing. ${ }^{12}$

Residents were therefore supposed to actively engage in the planning and construction of their own neighbourhoods, assisted by teams of architects, social workers, students and other technical staff who would assist them throughout the process. Between 1974 and 1976, 170 SAAL projects were set up, involving a total of 41,665 families, distributed over 2,259 houses (Conselho Nacional do SAAL, 1976).

As such, neighbourhood participation during the revolutionary period under the SAAL had specific features that made it significantly different from any other forms of neighbourhood participation that emerged later in the democratic regime. During the revolutionary period, the state itself was undergoing a process of transformation. The traditional hierarchies were not only challenged but completely dismantled and the path to a classless socialism was viewed by the relevant political agents as a real and viable option. Under these circumstances, the SAAL proposed a form of neighbourhood participation that can be categorized as transformative. Revolutionary in spirit, it entailed a significant transferal of decisional and executive power to self-organized neighbours that could thus have an effective influence on their own resettlement processes. It embodied an experiment in associative participatory democracy during a period of an intense reconfiguration of the political system that favoured such experimental governance schemes.

If it had been extended to other areas of urban planning beyond resettlement, this kind of organizational model could have generated something close to the right to the city, in its broadest and most ambitious sense. It was based on the effective empowerment of the most dispossessed citizens, which could have had equalizing effects that translated into a universal right to the spaces and opportunities available in the city, which would be largely public, given the socialist ideology. Of course this is no more than a debatable assumption that lacks empirical confirmation, since the scenario is hypothetical. The SAAL never became widespread; due to counter-reforming political measures, it remained a rather restricted experience, with a limited scope, both in terms of time and space.

In October 1976, the new constitutional government issued a regulation withdrawing power and leadership from the self-organized neighbours and teams, who were accused of overstepping the limits of the tasks they

12 Translation by the author. 
had been assigned and acting on the fringes of the state institutions and local authorities. As Ferreira (1975) suggests, the failure to comply with the proposed objectives may have due to the lack of any adequate support structure within which they could be pursued. Even during the revolution, neighbourhood organizations were viewed with suspicion by some of the more conservative sectors of the state. As a result, the ongoing projects met with bureaucratic and administrative difficulties, such as delays in expropriation orders or statements of the public utility of construction plots, or the absence of authorisations to finance projects, which meant they were blocked due to lack of funds.

Despite all the difficulties, the SAAL III National Council, which met in February 1976, decided not to further institutionalise and regulate the programme, which would hinder its independence. The Minister of Housing justified the termination of the SAAL by this same lack of institutionalization, accusing the teams of setting up a parallel power structure whose main purpose was political action, rather than solving local housing problems. Local residents protested strongly but were unable to reverse the process. The cause of the downfall of the process had been one of its greatest advantages - the flexibility derived from its institutional autonomy - which was subsequently presented as the main reason for its termination, precluding any possibility of revival (Bandeirinha, 2007). In the view of the main government agents, the democratic system that was taking its first faltering steps could not support such high levels of participation by potentially conflicting organizational structures that relied on a revolutionary rationale.

The sudden end to the SAAL left most projects unfinished, but many were already in progress and had to be incorporated into the new rationale of the political system: their main popular forces could be tamed into inclusive cooperation within the context of a stable democracy. The most significant aspect of the SAAL was its formal incentive for destitute residents of shanty towns to create democratic and horizontally organized secondary associations and their insertion in an essentially horizontal power structure. The importance of secondary associations for the quality of democracy, extensively scrutinized by Putnam et al. (1993), remains a fundamental aspect to consider, given its possible positive correlation with generalized reciprocity which, in turn, favours compliance with the requirements of democratic governance and enhances government accountability.

Fung (2003) argues that associations enhance democracy through the intrinsic value of associative life, by fostering civic virtues and teaching political skills, offering resistance to power and checking government, improving the quality and equality of representation, facilitating public deliberation, 
and creating opportunities for citizens and groups to participate directly in governance. However, the relationship between these aspects is not straightforward, since the causal relations between them are not necessarily direct and different kinds of associations contribute differently to each one. Moreover, enhancing democracy may mean different things in different political contexts. The advocates of a strictly representative democracy will necessarily have a different understanding from those who support participatory democracy. Thus the way in which associations evolve will reflect the role attributed to them by the major political and social forces over time.

In order to analyse the SAAL legacy beyond its ephemeral existence, it is fundamental to determine whether these neighbourhood organizations are still active, fulfil their commitment to manage the neighbourhoods, remain representative, inclusive and horizontally organized and continue to be regarded as legitimate actors by the state. Despite the SAAL's short-lived existence, the residents concerned had an intense participatory experience within the context of a programme that truly empowered them. It is therefore worth asking what happened to these neighbourhoods during 40 years of democracy, in an attempt to assess which factors made this participation possible, and the impact it had on spatial justice. Most of all, it is necessary to determine how participatory these residents remain: do the seeds of strong popular mobilization for broad social transformation still remain in these niches or were these popular organizations irrevocably tamed?

Local residents experiencing poverty and social exclusion - who were targeted by the SAAL - found themselves in a worse situation in the context of the revolution, in terms of the spatial distribution of resources and opportunities, since they were badly housed and could not afford access to the housing market. It was therefore at this level, where the side effects of inequality were greater, that participation had greater scope to produce consequences in terms of democratic quality: participation may oppose economic inequalities by granting power to the most dispossessed - the power to choose how and where they want to live. Now, in a context of severe economic crisis, the dormant revolutionary spirit may rise again, prompted by rising inequalities, social exclusion and poverty.

Revised by Sheena Caldwell

\section{References}

Bandeirinha, José António (2007), O Processo SAAL e a arquitectura no 25 de Abril de 1974. Coimbra: Imprensa da Universidade. 
Bingre do Amaral, Pedro (2011), Análise das relações da política de solos com o sistema económico - Estudo de enquadramento para a preparação da Nova Lei do Solo. Lisboa: Ministério do Ambiente e do Ordenamento do Território - Direção-Geral do Ordenamento do Território e do Desenvolvimento Urbano.

Carreiras, Marina; Amílcar, Anselmo; Ferreira, Bárbara, Malheiros, Jorge (2011), "Notas sobre a situação da habitação social em Portugal - Geografia, problemas e oportunidades?", Proceedings of the VIII Congresso da Geografia Portuguesa - Repensar a Geografia para novos desafios, 26 and 29 October. Lisboa: Associação Portuguesa de Geógrafos.

Conselho Nacional do SAAL (1976), Livro Branco do SAAL - 1974/1976. Vila Nova de Gaia: Conselho Nacional do SAAL

Fainstein, Susan (2009), “Spatial Justice and Planning”, Justice Spatiale, 1, September. Farinha Rodrigues, Carlos (ed.) (2012), Desigualdades económicas em Portugal. Lisboa: Fundação Francisco Manuel dos Santos.

Ferreira, Vítor Matias (1975), Movimentos sociais urbanos e intervenção política. Collection “A Cidade em Questão". Porto: Afrontamento.

Figueiredo, Rui Paulo (2004), Aníbal Cavaco Silva e o PSD (1985-1995) - A pós-consolidação do regime democrático português. Lisboa: Hugin Editores.

Fonseca Ferreira, António (1994), "Habitação social: Lições e prevenções para o PER", Sociedade e Território, 20, 8-10.

Fung, Archon (2003), “Associations and Democracy: Between Theories, Hopes and Realities”, Annual Review of Sociology, 29, 515-539.

Hall, Peter (2003), "Institutions and the Evolution of European Democracy", in Jack Hayward; Anand Menon (eds.), Governing Europe. Oxford: Oxford University Press, 1-14.

Harvey, David (2012), Rebel Cities - From the Right to the City to the Urban Revolution. London/New York: Verso.

INE - Instituto Nacional de Estatística (2013a), Conta Satélite da Economia Social. Lisboa: INE.

INE - Instituto Nacional de Estatística (2013b), Estatísticas da construção e babitação. Lisboa: INE.

IHRU - Instituto da Habitação e da Reabilitação Urbana (2007), Relatório 2 - Políticas de Habitação. Lisboa: ISCTE, IRIC/UP.

Kok, Wim (ed.) (2004), Facing the Challenge - The Lisbon Strategy for Growth and Employment. Brussels: European Commission.

Marques, Teresa Sá; Matos, Fátima Loureiro de; Guerra, Paula; Ribeiro, Diogo (2014), "Housing Problems in Portugal: A Challenge to Define a Territorialised Policy in Times of Crisis", presented at the Conference "The Welfare State in Portugal in the Age of Austerity, 9-10 May. Lisboa: ISEG.

Marx, Karl (1977), O capital. Viseu: Delfos. 
Namorado, Rui (1999), “Cooperativismo e política em Portugal”, in Carlos Barros; J. C. Gomes Santos (eds.), Cooperativismo, emprego e economia social. Lisboa: Vulgata, 96-115.

Pateman, Carole (1970), Participation and Democratic Theory. London: Cambridge University Press.

Procacci, Giovanna (1991), "Social Economy and the Government of Poverty", in Graham Burchell; Colin Gordon; Peter Miller (eds.), The Foucault Effect - Studies in Governmentality. Chicago: The University of Chicago Press, 151-168.

Putnam, Robert; Leonardi, Robert; Nanetti, Raffaella Y. (1993), Making Democracy Work: Civic Traditions in Modern Italy. Princeton: Princeton University Press.

Ramos Pinto, Pedro (2008), "Urban Social Movements and the Transition to Democracy in Portugal 1974-1976”, The Historical Journal, 51(4), 1025-1046.

Royo, Sebastián; Manuel, Paul Christopher (2003), Reconsidering Economic Relations and Political Citizenship in the New Iberia of the New Europe: Some Lessons from the Fifteenth Anniversary of the Accession of Portugal and Spain to the European Union. Center for European Studies, Working Paper No. 94.

Smismans, Stijn (2006), "Civil Society and European Governance: From Concepts to Research Agenda”, in Stijn Smismans (ed.), Civil Society and Legitimate European Governance. Cheltenham: Edward Elgar Publishing, 3-19.

Soja, Edward (2009), “The City and Spatial Justice”, Justice Spatiale, 1, september.

Received on 16.03.2015

Accepted for publication on 02.11.2015

\section{Camila Rodrigues}

CICS.NOVA Faculdade de Ciências Sociais e Humanas - FCSH/NOVA

Av. de Berna, 26 C, Ed. ID., 1069-061 Lisboa, Portugal

Contact: camilapombeiro@gmail.com

\section{A participação e a qualidade da Democracia em Portugal}

Partindo da discussão da contribuição da participação para a qualidade da democracia, procura-se situar esta problemática no contexto português. Em 40 anos, Portugal atravessou três conjunturas críticas: a revolução de abril, a adesão

\section{La participation et la qualité de la Démocratie au Portugal}

Partant du débat à propos de la contribution de la participation à la qualité de la démocratie, cet article vise à situer cette question dans le contexte portugais. En l'espace de 40 ans, le Portugal a connu 
à União Europeia e a crise económica. Os ideais revolucionários foram relegados para segundo plano à medida que novos ideais se impuseram, relacionados com a aposta na competitividade económica. Fenómenos de desigualdade, endividamento e precarização agravaram-se, originando reações que procuram reverter esta tendência. $\mathrm{O}$ aumento da participação poderá constituir uma reação interessante. Para além dos novos movimentos sociais, poderemos assistir à reativação de antigos movimentos que têm permanecido em estado latente, encapsulados em iniciativas como o SAAL (Serviço de Apoio Ambulatório Local), aguardando pela oportunidade de se manifestar novamente em prole da luta por uma sociedade mais inclusiva.

Palavras-chave: democracia participativa; movimentos urbanos; SAAL; sociedade inclusiva. trois phases cruciales: la révolution d'Avril, l'adhésion à l'Union européenne et la crise économique. Les idéaux révolutionnaires furent relégués à l'arrière-plan lorsque l'on vit apparaitre de nouveaux idéaux centrés sur la compétitivité économique. Des phénomènes d'inégalité, d'endettement et d'insécurité se sont aggravés et ont engendrés des réactions ayant pour but d'inverser cette tendance. Un accroissement de la participation pourrait en être une approche intéressante. En plus du nouveau mouvement social, d'anciens mouvements qui étaient restés latents, bloqués dans des initiatives telles que le SAAL [Service d'Appui Ambulatoire Local], peuvent être réactivés pour exprimer leur soutien à une société plus inclusive.

Mots-clés: démocratie participative; mouvements urbains; SAAL; société inclusive. 
